\title{
Evaluation of Urban Land Intensive Use in Wuhan City Based on Principal Component Analysis
}

\author{
Rui Zhang
}

\author{
Hubei University Business School, Hubei, China \\ *Corresponding author. Email:914829068@qq.com
}

\begin{abstract}
In the face of rapid urbanization in our country and the reality and the requirement of sustainable development, changing the mode of urban land use, improving the urban land use efficiency and benefit, and going the way of the intensive development of urban land are to solve the current contradiction between supply and demand of land in the process of the rapid development of urbanization in our country and the inevitable choice of realizing the sustainable development of city construction. This article uses the principal components analysis method and the comprehensive score method to calculate the analysis of urban land intensive use level in Wuhan city, for the future of Wuhan city to provide the reference and basis for further and intensive utilization of land. Through analysis, it can be found that the intensive use of urban land within the built-up area of Wuhan from 2013 to 2017 has been greatly improved. It is concluded that in the future economic development process, Wuhan should make the best use of the stock land in urban built-up areas, tap the utilization potential of the internal stock land, improve the land reserve capacity, and realize the orderly expansion of urban scale and the sustainable use of urban land.

Keywords: Land intensive use, principal component analysis, evaluation, Wuhan city
\end{abstract}

\section{INTRODUCTION}

With the rapid development of urbanization in China, the demand for urban construction land presents a trend of rapid growth. However, the basic national conditions of China with more people and less land and the farmland protection policy of dynamic balance of the total cultivated land in China cause a lot of restrictions on the supply of urban land. Therefore, changing the way of urban land use, improving the efficiency and benefit of urban land use, and taking the road of intensive development of urban land use are the inevitable choices to solve the contradiction between land supply and demand in the process of rapid urbanization in China and realize sustainable development of urban construction. Urban land intensive utilization is to realize the optimization of urban land comprehensive utilization benefits on the basis of comprehensive consideration of many factors affecting urban land utilization. The essence of urban land intensive utilization is to continuously improve land use efficiency and economic efficiency through increasing stock land investment and improving operation and management on the premise of rational distribution, optimizing land use structure and sustainable development. The evaluation of intensive use of urban land is a complex systematic project, which has been studied by many scholars at home and abroad. This paper takes Wuhan city as the research object, constructs the evaluation index system of urban land intensive use based on principal component analysis, conducts principal component analysis on the level of urban land intensive use in Wuhan city, and provides beneficial reference for promoting the urban land intensive use in Wuhan city.

Principal component analysis has the following functions: (1) principal component analysis can reduce the dimension of the data space studied. In other words, the $\mathrm{m}$ dimensional $Y$ space is studied to replace the $P$ dimensional $\mathrm{X}$ space ( $\mathrm{m}$ That is, when there is only one principal component $\mathrm{Y} 1$ (i.e., $\mathrm{m}=1$ ), this $\mathrm{Y} 1$ is still obtained by using all $\mathrm{X}$ variables $(\mathrm{P})$. For example, to calculate the mean of Y1, you have to use the mean of all the $x$ 's. In the first $m$ principal components selected, if the coefficients of a $\mathrm{Xi}$ are all close to zero, the $\mathrm{Xi}$ can be deleted, which is also a way to delete the redundant variables.

(2) Sometimes, some relationships between $\mathrm{X}$ variables can be clarified through the conclusion of factor load AIJ.

(3) A graphical representation method of multidimensional data. We know that geometry cannot be drawn when dimension is greater than 3 , and multivariate studies tend to have more than 3 variables. It is impossible to graphically represent the problem under study. After principal component analysis, however, we can choose the first two principal components or one of two principal components, according to the principal component scores, draw the $\mathrm{n}$ distribution condition of sample in $2 \mathrm{~d}$ plane, by the graphics can be visually see the status of each sample in the main component, which can also classify sample processing, can be found by the graphics from most sample points of outliers.

(4) The regression model is constructed by principal component analysis. In other words, each principal 
component is taken as a new independent variable to replace the original independent variable $\mathrm{X}$ for regression analysis.

(5) Principal component analysis was used to screen regression variables. The selection of regression variables has important practical significance. In order to make the model itself easy to do structural analysis, control and forecast, the best variable can be selected from the sub-set composed of original variables to form the best variable set. By using principal component analysis to select variables, the optimal variable quantum set can be selected with less computation.

In the transition period, the evaluation of urban land economical and intensive use is not only to better meet the challenge of "tight constraints" of resources and environment, but also to implement the strictest land management system, change the land use mode, and improve the efficiency and benefit of land use. It is also to optimize the allocation of space resources, improve urban functions and improve the quality of urban environment.

The research area of Wuhan, Wuhan, hereinafter referred to as "han", the nickname "river", is the capital of hubei province, the six provinces in central the only deputy provincial city and megalopolis, central China the center of the city, the Yangtze river economic belt core cities, and the national important industrial base, science and education base and comprehensive transport hub, logistic support of the central military commission garrison. Under its jurisdiction are 13 municipal districts, covering an area of $8,494.41$ square kilometers. In 2018 , the city had a permanent resident population of 1.081 million, with a regional GDP of 1.48 trillion yuan.

\section{INDEX SELECTION, DATA SOURCES AND RESEARCH METHODS}

\subsection{Construction of Wuhan Urban Land Intensive Use Evaluation System Based on Principal Component Analysis}

According to the connotation of urban land intensive utilization, reference the plan of urban land intensive utilization potential evaluation technology of specific requirements, at the same time to follow the index selection of comprehensive, typicality, quantifiable, operational principle, refer to the related research results, build the evaluation index system of urban land intensive use in Wuhan city, the index system of total factor includes 10 indicators (table 1).

Table 1 Evaluation index system of urban land intensive use

\begin{tabular}{|c|c|c|}
\hline indicators & meaning & instructions \\
\hline 1 & Population density $(10,000 / \mathrm{km})^{2}$ & $\begin{array}{c}\text { Measure population pressure on } \\
\text { urban land use }\end{array}$ \\
\hline 2 & $\begin{array}{l}\text { The added value of the secondary } \\
\text { industry accounts for } \% \text { of GDP }\end{array}$ & $\begin{array}{c}\text { Measure economic pressure on } \\
\text { urban land use }\end{array}$ \\
\hline 3 & $\begin{array}{l}\text { The added value of tertiary } \\
\text { industry accounts for } \% \text { of GDP }\end{array}$ & $\begin{array}{c}\text { Measure economic pressure on } \\
\text { urban land use }\end{array}$ \\
\hline 4 & $\begin{array}{c}\text { Green coverage rate of built-up } \\
\text { areas } \%\end{array}$ & $\begin{array}{c}\text { Measure environmental } \\
\text { constraints on urban land use }\end{array}$ \\
\hline 5 & $\begin{array}{l}\text { Gross industrial output value per } \\
\text { capita (100 million yuan } / \mathrm{km})^{2}\end{array}$ & $\begin{array}{l}\text { Measure the economic output of } \\
\text { urban land }\end{array}$ \\
\hline 6 & $\begin{array}{l}\text { Total retail sales of local social } \\
\text { goods (100 million yuan } / \mathrm{km})^{2}\end{array}$ & $\begin{array}{l}\text { Measure the economic output of } \\
\text { urban land }\end{array}$ \\
\hline
\end{tabular}




\begin{tabular}{|c|c|c|}
\hline 7 & $\begin{array}{l}\text { Local average fiscal revenue (100 } \\
\text { million yuan } / \mathrm{km})^{2}\end{array}$ & $\begin{array}{l}\text { Measure the economic output of } \\
\text { urban land }\end{array}$ \\
\hline 8 & $\begin{array}{l}\text { Local average financial input (100 } \\
\text { million yuan } / \mathrm{km})^{2}\end{array}$ & $\begin{array}{l}\text { Measure the intensity of urban } \\
\text { land input }\end{array}$ \\
\hline 9 & $\begin{array}{l}\text { Local real estate development } \\
\text { investment (100 million yuan } \\
\qquad / \mathrm{km})^{2}\end{array}$ & $\begin{array}{l}\text { Measure the intensity of urban } \\
\text { land input }\end{array}$ \\
\hline 10 & $\begin{array}{l}\text { Per capita construction land area } \\
\qquad \mathbf{M}^{2}\end{array}$ & Measure the use of urban land \\
\hline
\end{tabular}

\subsection{Data Sources}

Table 2 Indicators and data

\begin{tabular}{|c|c|c|c|c|c|c|c|c|c|c|}
\hline & $\begin{array}{c}\text { The } \\
\text { population } \\
\text { density is } \\
10,000 \text { per } \\
\text { square } \\
\text { kilometer }\end{array}$ & $\begin{array}{l}\text { The added } \\
\text { value of } \\
\text { the } \\
\text { secondary } \\
\text { industry } \\
\text { accounts } \\
\text { for } \% \text { of } \\
\text { GDP }\end{array}$ & $\begin{array}{c}\text { The added } \\
\text { value of } \\
\text { tertiary } \\
\text { industry } \\
\text { accounts } \\
\text { for } \% \text { of } \\
\text { GDP }\end{array}$ & $\begin{array}{l}\text { Green } \\
\text { coverage } \\
\text { rate of } \\
\text { built-up } \\
\text { areas \% }\end{array}$ & $\begin{array}{c}\text { The } \\
\text { average } \\
\text { industrial } \\
\text { output } \\
\text { value is } \\
100 \\
\text { million } \\
\text { yuan per } \\
\text { square } \\
\text { kilometer }\end{array}$ & $\begin{array}{l}\text { The total } \\
\text { retail value } \\
\text { of goods in } \\
\text { local } \\
\text { society is } \\
100 \\
\text { million } \\
\text { yuan per } \\
\text { square } \\
\text { kilometer }\end{array}$ & $\begin{array}{c}\text { The } \\
\text { average } \\
\text { local } \\
\text { revenue } \\
\text { is } 100 \\
\text { million } \\
\text { yuan } \\
\text { per } \\
\text { square } \\
\text { kilomet } \\
\text { er }\end{array}$ & \begin{tabular}{|c} 
The local \\
government \\
will invest \\
100 million \\
yuan per \\
square \\
kilometer
\end{tabular} & $\begin{array}{c}\text { Local real } \\
\text { estate } \\
\text { development } \\
\text { investment } \\
\text { of } 100 \\
\text { million yuan } \\
\text { per square } \\
\text { kilometer }\end{array}$ & $\begin{array}{c}\text { Per capita } \\
\text { construction } \\
\text { land square } \\
\text { meters }\end{array}$ \\
\hline 2017 & 9.95 & 43.71 & 53.25 & 39.55 & 0.67 & 0.73 & 0.17 & 0.2 & 0.32 & 8.2 \\
\hline 2016 & 10.19 & 43.88 & 52.84 & 39.65 & 0.62 & 0.66 & 0.16 & 0.18 & 0.3 & 8.54 \\
\hline 2015 & 10.24 & 45.68 & 51.02 & 39.19 & 0.59 & 0.6 & 0.15 & 0.16 & 0.3 & 8.42 \\
\hline 2014 & 10.28 & 47.53 & 49 & 38.87 & 0.56 & 0.51 & 0.13 & 0.14 & 0.28 & 8.22 \\
\hline 2013 & 10.33 & 48.57 & 47.72 & 38.85 & 0.52 & 0.46 & 0.2 & 0.13 & 0.22 & 8.28 \\
\hline
\end{tabular}

The main data are from the website of the National Bureau of Statistics. The indicators and data sorted out are shown in Table 2.The intensity of urban land use in Wuhan calculated by this study refers to the intensity of urban land use within all the built-up areas of Wuhan. Therefore, the urban land scope studied includes the sum of the urban built-up areas in the lower districts of Wuhan. 


\subsection{Research Methods}

Table 3 Variance of common factor
2.3.1. Principal component analysis was conducted with SPSS software, and the results were shown in the figure below

\begin{tabular}{|c|c|c|}
\hline & The initial & Extract \\
\hline $\begin{array}{l}\text { Population density board } \\
\text { ten thousand people/square } \\
\text { kilometers }\end{array}$ & 1.000 & 1.000 \\
\hline $\begin{array}{l}\text { The added value of the } \\
\text { secondary industry } \\
\text { accounted for } \% \text { of GDP }\end{array}$ & 1.000 & 1.000 \\
\hline $\begin{array}{l}\text { The added value of the } \\
\text { tertiary industry accounted } \\
\text { for } \% \text { of GDP }\end{array}$ & 1.000 & 1.000 \\
\hline $\begin{array}{l}\text { The green coverage rate of } \\
\text { the built-up area } \%\end{array}$ & 1.000 & .988 \\
\hline $\begin{array}{l}\text { Average industrial output } \\
\text { value of } 100 \text { million } \\
\text { yuan/square kilometers }\end{array}$ & 1.000 & 1.000 \\
\hline $\begin{array}{l}\text { The total retail sales of } \\
\text { social goods are } 100 \\
\text { million yuan/square } \\
\text { kilometers }\end{array}$ & 1.000 & .998 \\
\hline $\begin{array}{l}\text { Land revenue of } 100 \\
\text { million yuan per square } \\
\text { kilometer }\end{array}$ & 1.000 & .996 \\
\hline $\begin{array}{l}\text { An average of } 100 \text { million } \\
\text { yuan per square kilometer } \\
\text { was invested }\end{array}$ & 1.000 & 1.000 \\
\hline $\begin{array}{l}\text { Land average real estate } \\
\text { development investment of } \\
100 \text { million yuan/square } \\
\text { kilometers }\end{array}$ & 1.000 & .989 \\
\hline $\begin{array}{l}\text { Per capita construction } \\
\text { land square meters }\end{array}$ & 1.000 & .998 \\
\hline
\end{tabular}


Table 4 Total variance interpretation

\begin{tabular}{|c|c|c|c|c|c|c|}
\hline \multirow[b]{2}{*}{ composition } & \multicolumn{3}{|c|}{ Initial eigenvalue } & \multicolumn{3}{|c|}{ Extract the sum of the squares of the load } \\
\hline & A total of & $\begin{array}{l}\text { Variance } \\
\text { Hundred square }\end{array}$ & $\begin{array}{l}\text { The } \\
\text { cumulative } \%\end{array}$ & A total of & $\begin{array}{l}\text { Variance } \\
\text { Hundred square }\end{array}$ & $\begin{array}{c}\text { The } \\
\text { cumulative } \%\end{array}$ \\
\hline 1 & 7.494 & 74.935 & 74.935 & 7.494 & 74.935 & 74.935 \\
\hline 2 & 1.287 & 12.867 & 87.802 & 1.287 & 12.867 & 87.802 \\
\hline 3 & 1.188 & 11.878 & 99.681 & 1.188 & 11.878 & 99.681 \\
\hline 4 & .032 & .319 & 100.000 & & & \\
\hline 5 & $3.970 \mathrm{E}-16$ & $3.970 \mathrm{E}-15$ & 100.000 & & & \\
\hline 6 & 2.117E-16 & $2.117 \mathrm{E}-15$ & 100.000 & & & \\
\hline 7 & $1.188 \mathrm{E}-16$ & $1.188 \mathrm{E}-15$ & 100.000 & & & \\
\hline 8 & $-1.531 \mathrm{E}-17$ & $-1.531 \mathrm{E}-16$ & 100.000 & & & \\
\hline 9 & $-1.765 \mathrm{E}-16$ & $-1.765 \mathrm{E}-15$ & 100.000 & & & \\
\hline 10 & $-1.485 \mathrm{E}-15$ & $-1.485 \mathrm{E}-14$ & 100.000 & & & \\
\hline
\end{tabular}

Table 5 Component matrix

Extraction method: principal component analysis

\begin{tabular}{|c|c|c|c|}
\hline & comp & & \\
\hline & 1 & 2 & 3 \\
\hline $\begin{array}{l}\text { Population density board ten thousand people/square } \\
\text { kilometers }\end{array}$ & -.878 & .479 & -.009 \\
\hline $\begin{array}{l}\text { The added value of the secondary industry accounted } \\
\text { for } \% \text { of GDP }\end{array}$ & -.989 & -.123 & -.077 \\
\hline $\begin{array}{l}\text { The added value of the tertiary industry accounted for } \\
\% \text { of GDP }\end{array}$ & .994 & .099 & .050 \\
\hline The green coverage rate of the built-up area $\%$ & .943 & .176 & .261 \\
\hline $\begin{array}{l}\text { Average industrial output value of } 100 \text { million } \\
\text { yuan/square kilometers }\end{array}$ & .987 & -.155 & -.053 \\
\hline $\begin{array}{l}\text { The total retail sales of social goods are } 100 \text { million } \\
\text { yuan/square kilometers }\end{array}$ & .996 & -.063 & .042 \\
\hline Land revenue of 100 million yuan per square kilometer & -.199 & -.356 & .911 \\
\hline $\begin{array}{l}\text { An average of } 100 \text { million yuan per square kilometer } \\
\text { was invested }\end{array}$ & .989 & -.119 & .088 \\
\hline
\end{tabular}




\begin{tabular}{|l|l|l|l|}
\hline $\begin{array}{l}\text { Land average real estate development investment of } \\
100 \text { million yuan/square kilometers }\end{array}$ & .909 & .084 & -.394 \\
\hline Per capita construction land square meters & .243 & .908 & .338 \\
\hline
\end{tabular}

Extraction method: principal component analysis

Three components were extracted

\subsubsection{Comprehensive score calculation method}

Calculated according to the 2013-2017 in Wuhan urban land intensive utilization of each principal component factor score, then the variance contribution rate of each principal components as weight, finally each principal component factor score and the contribution rate of each principal component variance product divided by the sum of cumulative variance contribution rate can reach Wuhan range 2013-2017 composite scores of urban land intensive utilization, the formula is as follows:

$$
F_{i}=\frac{72.365 F_{1}+13.911 F_{2}+13.405 F_{3}}{99.681}
$$

In the formula, $\mathrm{F}$ represents the principal component comprehensive score of WuhanWuhan's urban land intensive utilization in the ith year (the weight is the value obtained after rotation). ${ }^{\mathrm{i}}$

\section{RESULTS AND ANALYSIS}

\subsection{Select Principal Component According to the Cumulative Contribution Rate of Variance the composition matrix after rotation}

Table 6 The composition matrix after rotation
Using SPSS statistical analysis software operation, Wuhan urban land intensive utilization factor characteristic root of factor value, and according to the principle of characteristic roots is greater than 1 for selecting principal components, according to the results of the SPSS statistical analysis can select top three characteristic root is given priority to composition, cumulative variance contribution rate as $99.681 \%$, indicates that the variable (pca) already contains $99.681 \%$ of the original variable information.

\subsection{Factor Extraction Results and Factor Regression Coefficient}

According to the initial factor extraction results of urban land intensive utilization in Wuhan obtained by SPSS, as it cannot clearly reflect the index information contained in the principal components, it is necessary to carry out the maximum rotation of orthogonal variance on the initial factor extraction results, and then obtain the rotated component matrix diagram.

\begin{tabular}{|c|c|c|c|}
\hline & \multicolumn{3}{|c|}{ composition } \\
\hline & 1 & 2 & 3 \\
\hline $\begin{array}{l}\text { Population density board ten thousand people/square } \\
\text { kilometers }\end{array}$ & -.947 & .318 & -.042 \\
\hline $\begin{array}{l}\text { The added value of the secondary industry accounted for } \\
\qquad \% \text { of GDP }\end{array}$ & -.953 & -.277 & .119 \\
\hline $\begin{array}{l}\text { The added value of the tertiary industry accounted for } \% \text { of } \\
\text { GDP }\end{array}$ & .960 & .246 & -.137 \\
\hline The green coverage rate of the built-up area $\%$ & .915 & .386 & .041 \\
\hline $\begin{array}{l}\text { Average industrial output value of } 100 \text { million yuan/square } \\
\text { kilometers }\end{array}$ & .989 & -.026 & -.144 \\
\hline $\begin{array}{c}\text { The total retail sales of social goods are } 100 \text { million } \\
\text { yuan/square kilometers }\end{array}$ & .991 & .094 & -.088 \\
\hline
\end{tabular}




\begin{tabular}{|c|c|c|c|}
\hline Land revenue of 100 million yuan per square kilometer & -.047 & -.026 & .997 \\
\hline $\begin{array}{l}\text { An average of } 100 \text { million yuan per square kilometer was } \\
\text { invested }\end{array}$ & .998 & .059 & -.025 \\
\hline $\begin{array}{l}\text { Land average real estate development investment of } 100 \\
\text { million yuan/square kilometers }\end{array}$ & .839 & .060 & -.530 \\
\hline Per capita construction land square meters & .103 & .993 & -.034 \\
\hline
\end{tabular}

Extraction method: principal component analysis Rotation method: Kaiser normalized maximum variance method The rotations converge after four iterations

Table 7 Compositional rotation matrix

\begin{tabular}{|c|c|c|r|}
\hline composition & 1 & 2 & 3 \\
\hline 1 & .979 & .138 & -.150 \\
\hline 2 & -.182 & .922 & -.342 \\
\hline 3 & .091 & .362 & .928 \\
\hline
\end{tabular}

Extraction method: principal component analysis

Table 8 Total variance interpretation Rotation method: Kaiser normalized maximum variance method

\begin{tabular}{|c|c|c|c|c|c|c|c|c|c|}
\hline \multirow[b]{2}{*}{$\begin{array}{c}\text { composi } \\
\text { tion }\end{array}$} & \multicolumn{3}{|c|}{ The initial value } & \multicolumn{3}{|c|}{$\begin{array}{l}\text { Extract the sum of the squares of the } \\
\text { load }\end{array}$} & \multicolumn{3}{|c|}{$\begin{array}{c}\text { Sum of the squares of the rotational } \\
\text { loads }\end{array}$} \\
\hline & A total of & $\begin{array}{c}\text { Variance } \\
\text { Hundred } \\
\text { square ratio }\end{array}$ & $\begin{array}{c}\text { The } \\
\text { cumulative } \\
\%\end{array}$ & A total of & $\begin{array}{c}\text { Variance } \\
\text { Hundred } \\
\text { square ratio }\end{array}$ & $\begin{array}{c}\text { The } \\
\text { cumulative } \\
\%\end{array}$ & A total of & $\begin{array}{c}\text { Variance } \\
\text { Hundred } \\
\text { square ratio }\end{array}$ & $\begin{array}{c}\text { The } \\
\text { cumulative } \\
\%\end{array}$ \\
\hline 1 & 7.494 & 74.935 & 74.935 & 7.494 & 74.935 & 74.935 & 7.236 & 72.365 & 72.365 \\
\hline 2 & 1.287 & 12.867 & 87.802 & 1.287 & 12.867 & 87.802 & 1.391 & 13.911 & 86.275 \\
\hline 3 & 1.188 & 11.878 & 99.681 & 1.188 & 11.878 & 99.681 & 1.341 & 13.405 & 99.681 \\
\hline 4 & .032 & .319 & 100.000 & & & & & & \\
\hline 5 & $3.970 \mathrm{E}-16$ & $3.970 \mathrm{E}-15$ & 100.000 & & & & & & \\
\hline 6 & $2.117 \mathrm{E}-16$ & $2.117 \mathrm{E}-15$ & 100.000 & & & & & & \\
\hline 7 & $1.188 \mathrm{E}-16$ & $1.188 \mathrm{E}-15$ & 100.000 & & & & & & \\
\hline 8 & $-1.531 \mathrm{E}-17$ & $-1.531 \mathrm{E}-16$ & 100.000 & & & & & & \\
\hline 9 & $-1.765 \mathrm{E}-16$ & $-1.765 \mathrm{E}-15$ & 100.000 & & & & & & \\
\hline 10 & $-1.485 \mathrm{E}-15$ & $-1.485 \mathrm{E}-14$ & 100.000 & & & & & & \\
\hline
\end{tabular}

It can be seen from the composition matrix after rotation in the figure above that the first principal component has a large load in the proportion of the added value of the tertiary industry in GDP, the green coverage rate of the built-up area, the average industrial output value, the average retail sales volume of commodities, the average financial investment and the average real estate development investment. $F_{1}$ The second principal component has the largest load on per capita construction
Extraction method: principal component analysis land. $F_{2}$ The third principal component has the largest load on the average local fiscal revenue. $F_{3}$ 


\subsection{Comprehensive Score of Urban Land \\ Intensive Use in Wuhan from 2013 to 2017}

Table 9 Comprehensive score of urban land intensive use in Wuhan from 2013 to 2017

\begin{tabular}{|c|c|c|c|c|c|c|}
\hline year & $F_{1}$ & $F_{2}$ & $F_{3}$ & $F_{\text {综 }}$ & $\begin{array}{c}\text { Composite } \\
\text { scores }\end{array}$ & ranking \\
\hline 2013 & 1.07208 & 0.20206 & 1.41767 & 0.14353 & 0.78719 & 4 \\
\hline 2014 & 0.76743 & 0.71086 & 1.24829 & 2.72658 & 0.82420 & 5 \\
\hline 2015 & 0.09901 & 0.53598 & 0.55775 & 0.12078 & 0.07208 & 3 \\
\hline 2016 & 0.53744 & 1.43256 & 0.04341 & 2.01341 & 0.59592 & 2 \\
\hline 2017 & 1.40109 & 1.05562 & 0.34497 & 0.69044 & 0.91622 & 1 \\
\hline
\end{tabular}

As can be seen from the above table, the comprehensive score of Intensive use of urban land in Wuhan increased from -0.78719 to 0.91622 from 2013 to 2017. Except for the temporary decline in the comprehensive score from 2013 to 2014, it basically increased gradually and at a relatively fast rate, which was in line with the actual situation of urban economic development and urban land use in Wuhan from 2013 to 2017. The results show that the statistical analysis based on principal component analysis (PCA) is feasible and can better reflect the actual situation of WuhanWuhan urban land use. In recent years, with the state's emphasis and emphasis on the sustainable development of urban construction, Wuhan is also actively responding to the relevant national policies and steadily promoting the sustainable development of urban construction. In recent years, with WuhanWuhan city vigorously of the implementation of the old city reconstruction, especially in the mature urban infrastructure, as a result of the urban land price and house prices continue to rise, after a lot of old building demolition low converted into high-level commercial residential buildings, greatly improving the city proper of the stock of land intensive utilization degree, result in WuhanWuhan within the scope of the urban land intensive utilization degree increases significantly. This also for the future, therefore, raise the level of WuhanWuhan urban land intensive utilization pointed out the direction, that is in the process of the economic development of WuhanWuhan city in the future to make the most of the city proper stock land, excavate the urban stock land use potential, improve the land reserve capacity, orderly implementation of Wuhan city scale expansion and the sustainable utilization of urban land.

\section{CONCLUSION}

Wuhan city's urban land intensive utilization is a rather complex systematic project, which contains many impact factors. Therefore, it is necessary to pay attention to the system feedback capacity construction and greatly improve the contribution value of each impact factor of the corresponding subsystem to the land intensive utilization goal. At the same time of improving WuhanWuhan's social and economic development level, the negative pressure on WuhanWuhan's urban land use can be reduced as much as possible, and the intensive utilization of WuhanWuhan's urban land resources can be maintained and improved. There are many factors affecting the intensive use of urban land in Wuhan, and it is also difficult to collect data. Therefore, how to select the index system of intensive use of urban land in Wuhan is the most important link, and the accuracy of data also has a great impact on the measurement results. However, the intensive utilization of land use in WuhanWuhan city selected in the study is only a part of the important indicators, which fails to understand all aspects of urban land intensive utilization situation in detail. The research ability is limited, in the future, the data of urban land intensive use in Wuhan should be collected systematically, and the index system of urban land intensive use in Wuhan should be improved.

\section{REFERENCES}

[1] Zhou Xiaoyan, Feng Zhunzhun, Kang Chun. A Study on spatial Difference of intensive land use in Wuhan Urban circle [J]. Journal of central China normal university (natural science edition), 2008, 42 (1): 119-123.

[2] Deng Zhi, Hang Yanhong, Xu Zhi. Evaluation of Intensive Land Use in Qiqihar City based on PSR Model [J]. Science and technology management of land and resources, 2011, 28 (1): 62-66.

[3] Li Xinxin, Zhang Anming. Evaluation of Intensive land Use in Chongqing from the perspective of low carbon [J]. Soil and water conservation research, 2014, 21 (4): 268-273. 
[4] Chen Yanbei, Zhou Jiahe, Shen Danfeng, et al. Evaluation of intensive land Use in Zhoushan Archipelago New Area based on PSR Model [J].Journal of Hangzhou Normal University (Natural Science edition), 2014(2) : 220-224.

[5] Zhan Haibin, Wu Qun. Spatial Difference Analysis of Urban Land Intensive Use Based on PSR Model: A case study of Jiangsu Province [J].Agricultural systems science and integrated research, 2009, 25 (4): 396-400.

[6] Li Weiyi. Study on urban Land Intensive Utilization Based on PSR Model: A case study of Beijing [J]. China Real Estate (Academic edition), 2016(12): 49-55.

[7] Wang Peng, Kuang Fumin, Deng Yuwu, et al. Evaluation of land Ecological security in Hengyang City based on principal component Analysis [J]. Economic geography, 2015, 35 (1): 168-172.

[8] Zhan Haibin. Evaluation of urban land intensive Use in Xiangyang City based on principal component analysis $[\mathrm{J}]$. Anhui agricultural science, 2017,45(33):201-203.

[9] Chen Yu. Analysis and Policy Research on Potential Exploitation of Urban Land Intensive Use [D].

Huazhong Agricultural University, 2012.

[10] Wang Yanyan, Mei Yun. Countermeasures for intensive utilization of urban land in Wuhan city [J]. Science and technology management of land and resources, 2011, 28(01):7-14. 